\title{
Program Accreditation: Developing a Methodology to Retrieve and Maintain Relevant Data for Course Improvement and Provide an Assessment Process Which Closes the Loop
}

\author{
Mr. Veto Matthew Ray, Indiana University Purdue University, Indianapolis
}

Mr. Matt Ray is a lecturer for the Construction Engineering Management Technology Program offered through the Purdue School of Engineering and Technology at Indiana University Purdue University Indianapolis. He currently provides instruction for Soils and Foundations, Construction Cost and Bidding, Construction Project Cost and Production Control as well as managing the Certificate of Training in Asset Management. He is a graduate of Purdue School of Engineering and Technology receiving degrees in Construction Technology, Architectural Technology, and a Masters in Facility Management. His field experience includes residential construction and light commercial. He has been an architectural designer as well as a superintendent for single and multi-family construction projects. Mr. Ray worked as an engineering and design manager in the Building Component Manufacturing Industry for over fifteen years.

\section{Mr. J, William White, Indiana University Purdue University, Indianapolis}

J. William White AIA is a lecturer with the Construction Engineering Management Technology program within the Purdue School of Engineering and Technology in Indianapolis. He is a registered architect who has more than 23 years of varied construction industry experience. Mr. White has undergraduate degrees from Indiana University and Ball State University and a masters degree from Purdue University Indianapolis. He is an active member of the American Institute of Architects and the Construction Specifications Institute. His professional interests include great architecture and all things related to construction innovation.

\section{Dr. Dan D Koo P.E., Indiana University Purdue University, Indianapolis}

Dr. Koo is an assistant professor in the department of engineering and technology at Indiana University and Purdue University Indianapolis (IUPUI). Dr. Koo is also a registered PE. Dr. Koo's research and professional activities are primarily focused on heavy civil infrastructure system, underground infrastructure system management and development, trenchless engineering, and sustainability. Dr. Koo received a Ph. D in Civil and Environmental Engineering and MS in Construction Management at Arizona State University in 2007 and 2003 respectively; and a BE degree in Civil Engineering in 1999. 


\section{Program Accreditation: Developing a Methodology to Retrieve and Maintain Relevant Data for Course Improvement and Provide an Assessment Process Which Closes the Loop}

\section{Introduction}

Continuous improvement, quality control, and customer satisfaction are all terms found to be common place in today's business models. Ideas that originated to support the manufacturing industry have expanded to not only support the production of goods but to also support businesses whose products constitute a provided service or services. The realm of higher education has not escaped the influence of these philosophies and methods. Accrediting bodies for higher education have evolved to ensure both quality and improved education. According to the United States Department of Education, the goal of accreditation is to ensure that education provided by institutions of higher education meets acceptable levels of quality (USDE, 2013) ${ }^{7}$. ABET, providing accreditation for academic programs, includes continuous improvement as one of its criteria for accrediting programs (ABET, 2013) ${ }^{1}$. The Indiana Commission for Higher Education is urging higher education institutes, similar to other businesses, to provide a product faster and more affordable without reducing the quality of education (ICHE, 2013) ${ }^{5}$. Though accrediting bodies have specific guidelines to assist in identifying the results of an assessment program it is the individual institutes and programs that are responsible for developing, launching and managing their respective assessment structures.

The focus of this endeavor was to define a cyclical process of meaningful data collection for course evaluation and timely review. By clearly defining methods and purpose, faculty and overall programs can improve their ability to track pitfalls, reduce the time spent gathering ambiguous information and increase opportunity for course and program improvement. The primary target of this evaluation was to retrieve and maintain relevant data and show proof of an assessment process to meet the requirements for ABET accreditation as well as North Central Accreditation (NCA). As higher education evolves and competition increases for funding it is imperative that academic departments and programs strive for excellence. By improving data collection for course evaluation and maintaining accreditation, the department increases its ability to attract students, influence the procurement of research dollars and reduce counterproductive efforts gathering information that has no useful application. Both research dollars and financial aid are dependent upon the ability to earn or maintain accreditation. Generally, a school must be accredited by a nationally recognized accrediting agency or association to be eligible to participate in Federal Student Aid programs (FSA, 2013) ${ }^{3}$. In 2013 research dollars for the university exceeded 300 million dollars (IUPUI Institutional Reports, 2013) ${ }^{4}$ and $69.8 \%$ of all students enrolled received some form of need-based financial assistance (College.USNews, 2013) ${ }^{2}$. This report will illustrate Six Sigma project phases and highlight key tools incorporated to produce a program assessment process for program assessment, improvement, and accreditation data preparation.

\section{Background}

To obtain continuous ABET accreditation, comprehensive general reviews must be conducted for each accredited program at intervals no longer than six years. Interim reviews may occur 
between general reviews if and when a weakness or deficiency is noted in the general review. The last general review for a majority of the programs belonging to the Department of Engineering Technology was scheduled for 2013. Among other items, the review covered the individual program's ability to assess its students and verify that each program maintains a closed-loop process for continuous program improvement. In preparation for ABET's general review, which included a site visit, the department chair chose to accept this as an opportunity to identify the department's assessment process more clearly. The department had previously taken part in a reorganization instituted at the school level. The reorganization eliminated some departments while shifting multiple programs into the newly formed Department of Engineering Technology with the premise of fostering interdisciplinary collaboration. It was quickly realized that though assessment was taking place among the programs, a level of congruency in the department was missing. What originally had been identified as a Six Sigma process improvement project, with the hope of building on an existing plan, was reinvented as a Design for Six Sigma project to better serve the department's needs.

\section{Experimental Method}

The most common pathway proposed for Lean Six Sigma process improvement is often referred to as the DMAIC process represented by a cycle of define, measure, analyze, improve and control. Nevertheless, this being the most common course for improvement did not make it the most appropriate course to accomplish the department's goals. Design for Six Sigma, as if there was no existing process, rather than DMAIC process improvement is more applicable when a business chooses to replace one or more core processes and/or when the leadership team discovers that improving an existing process will not deliver the level of quality demanded (Pande, Neuman and Cavanagh, 2002) ${ }^{6}$.

The Six Sigma DMADV Methodology was utilized for this investigation and is summarized below:

Define customer requirements and goals for the process/product/service.

Measure and match performance to customer requirements.

Analyze and assess process/product/ service design.

Design and implement new processes/products/services.

Verify results and maintain performance.

Each step or phase of the DMADV process involves several tools to complete each task. Key tools and their applications will be highlighted to demonstrate steps incorporated into the project. Due to the size of the project some tools and applications have been excluded from this report.

\section{Define Phase}

During the define phase the leadership team worked to determine and document the projects problem statement, objective, scope, goal and deliverables to form the project charter seen in Figure 1. 
- Problem Statement: There exists a lack of clarity, uniformity and purpose in the collection and application of useful data for course and program improvement as well as accreditation review across departmental programs.

o Impact: This reduces a program's ability to achieve maximum student satisfaction, equip students to meet learning objectives and compile evidence supporting assessment programming to maintain accreditation.

- Project Objective: Improve collection of data and evaluation of courses for program enrichment and accreditation assessment.

- Project Scope: The process being evaluated initiates with course offerings beginning in the fall semester and ends with a semester reflection and program review in the spring.

- Goal Statement: Develop methodology within the 12-16 weeks allotted that provides consistent data collection and evaluation of courses for program enrichment and accreditation assessment to reduce reactive measures taken to provide assessment documentation.

- Deliverables: Reflection Packet Template, Data Collection Plan, Process Map, Process Observation Sheet, Reflection Checksheet

\begin{tabular}{|c|c|c|}
\hline & \multicolumn{2}{|c|}{ Project Name: } \\
\hline Date Chartered: & Start Date: & Target Completion Date: \\
\hline \multirow[t]{10}{*}{ Project Team } & Phone/email & Title \\
\hline & & Project Lead \\
\hline & & Department Chair \\
\hline & & Assistant to Chair \\
\hline & & Program Director \\
\hline & & Program Director \\
\hline & & Program Director \\
\hline & & Program Director \\
\hline & & Faculty \\
\hline & & Faculty \\
\hline \multirow[t]{2}{*}{ Process Owner } & Phone /email & Title \\
\hline & & Department Chair \\
\hline \multicolumn{3}{|c|}{ Problem Statement } \\
\hline \multicolumn{3}{|l|}{$\begin{array}{l}\text { There exists } \\
\text { for course a }\end{array}$} \\
\hline \multicolumn{3}{|l|}{ Goal Statement } \\
\hline $\begin{array}{l}\text { Develop m } \\
\text { evaluation } \\
\text { measures }\end{array}$ & $\begin{array}{l}\text { ithin the } 12-16 \text { weeks } \\
\text { r program enrichment } \\
\text { de assessment inforn }\end{array}$ & $\begin{array}{l}\text { provides consistent data collection and } \\
\text { tation assessment to reduce reactive }\end{array}$ \\
\hline \multicolumn{3}{|l|}{ Project Scope } \\
\hline \multicolumn{3}{|r|}{$\begin{array}{l}\text { tion of courses for program enrichment } \\
\text { the course offerings for fall semester } \\
\text { mpletion of the spring semester. }\end{array}$} \\
\hline \multicolumn{3}{|c|}{ Project Deliverables } \\
\hline \multicolumn{3}{|c|}{$\begin{array}{l}\text { Include Reflection Packet Template, Data Collection Plan, Process Map, Process Observation Sheet, } \\
\text { Reflection Checksheet }\end{array}$} \\
\hline
\end{tabular}

Figure 1 Project Charter 
Ultimately a process exists to serve the needs of its customers. Accrediting bodies could be viewed as customers that each program seeks to satisfy, but it is the faculty and staff that act as the end-user of the process. In the design phase customers were identified and their needs analyzed to ensure that the process would produce a favorable outcome. A Voice of the Customer (VOC) analysis was performed by interviewing other front line staff and faculty members not on the project team. Each was asked to offer responses to 4 key questions.

1. What are the strengths associated with the existing evaluation and assessment components/processes related to the program enrichment process?

- The student “end of semester course evaluations” gives students an opportunity to have a voice in the process.

- The student “end of semester course evaluations” can provide valuable feedback to instructors for course improvement.

- The faculty "end of semester course reflection" requires faculty to pause and think about course accomplishments or shortcomings.

- The use of PULs and ABET outcomes impose some trackable learning objectives for each course.

- The current components/processes give individual instructors the ability to selfassess their course.

- The current components/processes achieved the goal of receiving ABET accreditation.

- The current components/processes create discussion that otherwise may not have happened.

2. What are the weaknesses within these components/processes?

- It can be difficult creating student interest in the student "end of semester course evaluations".

- The student “end of semester course evaluations" can be used as a means to vent rather than an avenue for constructive criticism.

- The timeliness of student "end of semester course evaluations" do not serve to correct current course issues only future ones.

- The student "end of semester course evaluations" has a tendency to focus on likeability of instructor rather than course objectives, facilities and lab provisions.

- The faculty “end of semester course reflection” has redundant questions.

- There exists some ambiguity in the understanding of PULs and ABET outcomes along with their ability to truly discern course results.

- There is a lack of recognizable training on the use of PULs and ABET outcomes

- There is a lack of accountability for completing or applying any of the evaluation and assessment components/processes.

- There is currently not enough emphasis from the department chair or program directors to follow through with the completion of any evaluation documentation.

- There is no existing consistent process in place for using evaluation and assessment components. 
3. What are the opportunities for improvement within these components/processes?

- The introduction of student "mid-semester course evaluations" would help steer new courses as well as new faculty members in a productive direction.

- The addition of allotted space at the end of the faculty "end of semester course reflection" to allow for action items regarding course improvement.

- The creation of a database to store the faculty "end of semester course reflection".

- The addition of assessment training to educate new hires as well as offer a refresher every few years for existing faculty and staff.

- The introduction of peer evaluation for new full and part-time faculty members.

- The review of student "end of semester course evaluations" by the program director or course coordinator.

- The addition of an assessment coordinator position to help with stream lining the process as well as keeping programs aware of any changes in the accreditation process.

4. What could potentially threaten the success of this project team?

- The lack of faculty buy-in would inhibit the process.

- The lack of part-time faculty buy-in would inhibit the process.

- The perception of inadequate staffing and support for the extra work load would limit the success.

- The lack of awareness and understanding of the process would limit the diffusion of the process.

- The inability to standardize the process across the department would also stifle the effectiveness of the project.

VOC analysis indicated that although some individual components yielded positive results, a lack of direction and training forfeited maximum results. Without an emphasis placed on a required consistent process, the faculty perception was that the components were optional and of limited value. That is not to say that faculty members were not assessing students and making improvements to individual courses and programs, but the intent of this project was to identify one over-riding process to create congruency between the department's programs while allowing some level of autonomy.

Other important tasks performed during the define phase included a stakeholder analysis, identifying each stakeholder and their relationship to the process, a simple project schedule including milestones, and a SIPOC model (Figure 2) which acts as a high-level process map. At the end of each phase a Tollgate review or formal review was performed to achieve managerial approval to move to the next phase. 


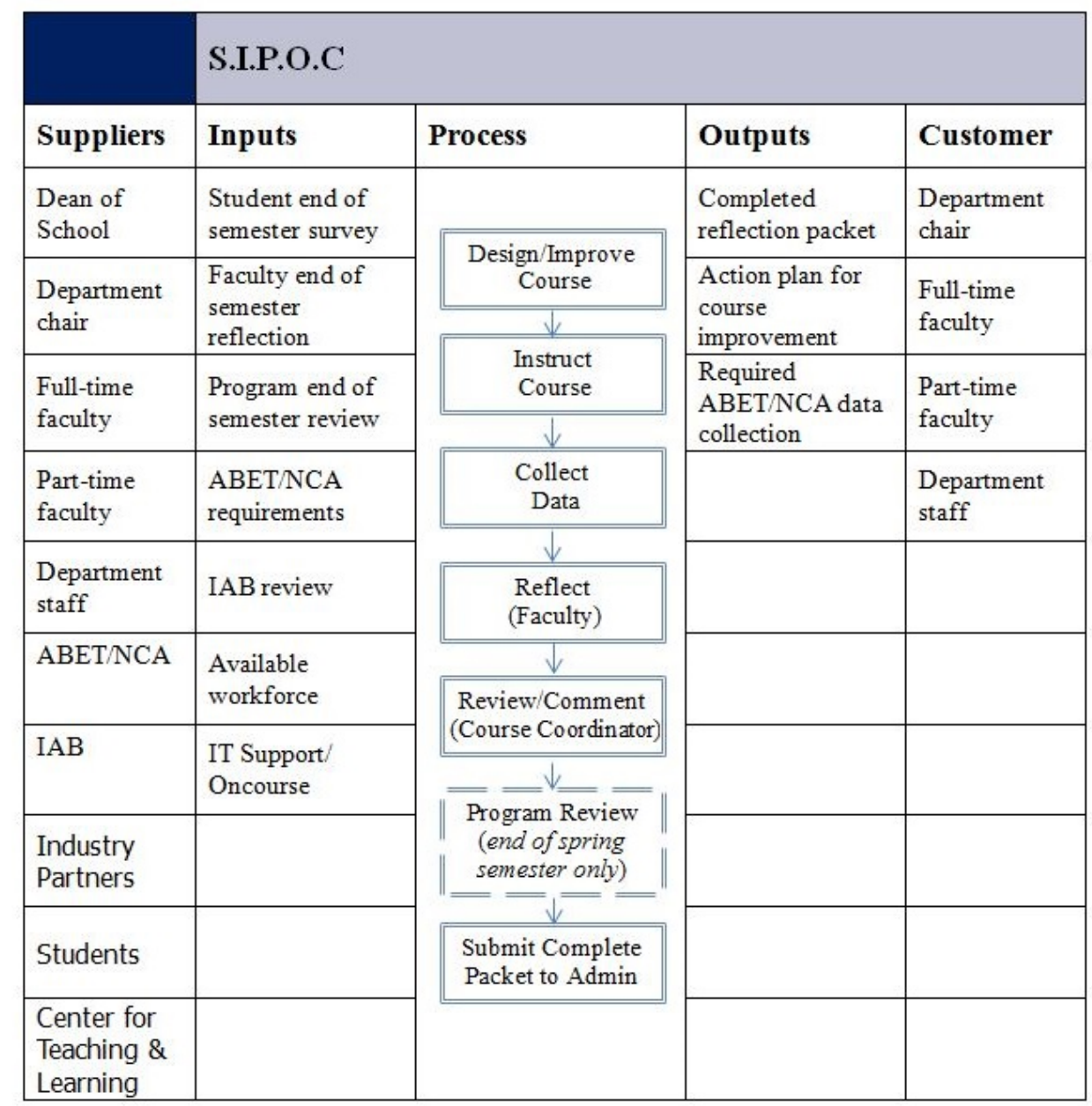

Figure 2 SIPOC Model

\section{Measure Phase}

During the measure phase, components which were critical to quality were determined using a critical to quality (CTQ) tree (Figure 3a-3c). The components deemed to be CTQ included; accuracy and relevance of the data collected, whether or not the data being submitted followed the specified format and if the reflection packet had been completed by faculty. A baseline measurement (direct and indirect) of the following Key Process Output Variables (KPOVs) and Key Process Input Variables (KPIVs) was completed.

- Process communication by the department chair (KPIV)

- Availability of training resources to complete reflection packet (KPIV)

- Time to complete reflection packet (KPIV)

- Reflection packet submitted (KPOV)

Surveys were created and distributed to all full-time faculty to collect indirect measurements for the KPIVs due to their subjective nature and the lack of historical data. A direct measurement for reflection document submittal was based on historical data obtained from collection of reflection documentation covering the previous 4 semesters. 


\begin{tabular}{|c|c|c|c|}
\hline Customer(s) & \multirow[b]{3}{*}{$\begin{array}{l}\text { Data presented in } \\
\text { specified format }\end{array}$} & KPOV(s) & $\begin{array}{l}\text { KPIV(s) } \\
\qquad \begin{array}{l}\text { Faculty years of } \\
\text { experience }\end{array}\end{array}$ \\
\hline Department chair & & \multirow[b]{2}{*}{$\begin{array}{l}\text { Faculty complied w/ } \\
\text { specified format }\end{array}$} & $\begin{array}{l}\text { Availability of faculty } \\
\text { time/ workload }\end{array}$ \\
\hline Full-time faculty & & & $\begin{array}{l}\text { Communication of } \\
\text { process by Department } \\
\text { Chair-Program Director } \\
\text {-Course Coordinator }\end{array}$ \\
\hline Part-time faculty & & & $\begin{array}{l}\text { Reflection packet } \\
\text { template provided }\end{array}$ \\
\hline \multirow[t]{2}{*}{ Department staff } & & & $\begin{array}{l}\text { Difficulty level for } \\
\text { packet completion }\end{array}$ \\
\hline & & & $\begin{array}{l}\text { Training resources and } \\
\text { instructions made } \\
\text { available }\end{array}$ \\
\hline
\end{tabular}

Figure 3(a) CTQ Tree

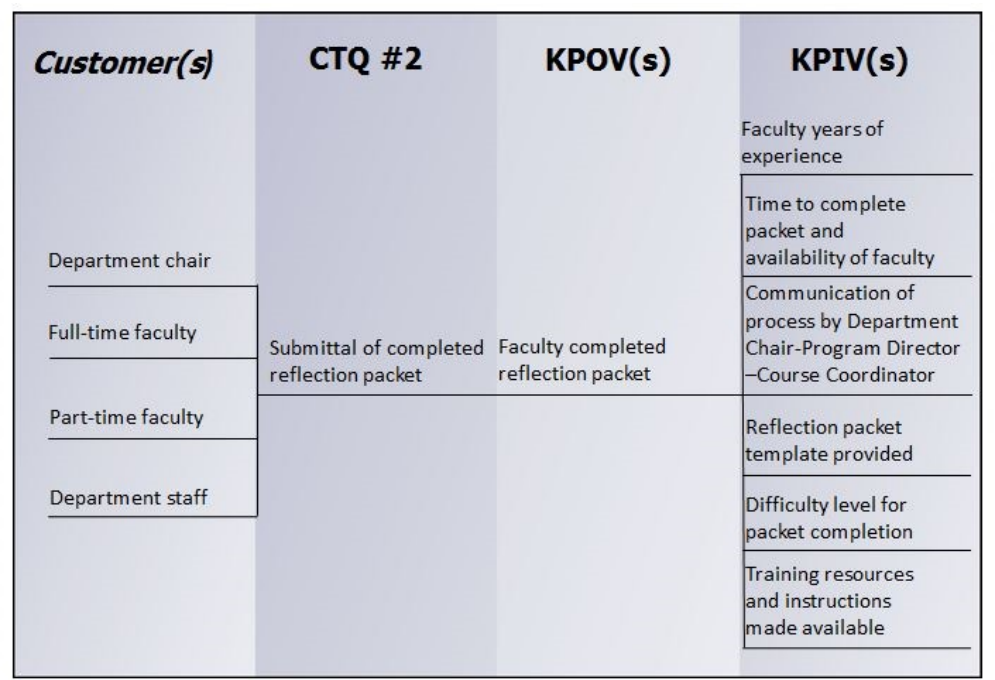

Figure 3(b) CTQ Tree

\begin{tabular}{|c|c|c|c|}
\hline Customer(s) & \multirow[b]{3}{*}{$\begin{array}{l}\text { Accuracy/Relevance } \\
\text { of Data }\end{array}$} & \multirow[b]{3}{*}{$\begin{array}{l}\text { ABET outcomes/PULs } \\
\text { specified were } \\
\text { collected }\end{array}$} & $\begin{array}{l}\qquad \mathbf{K P I V ( s )} \\
\qquad \begin{array}{l}\text { Faculty years of } \\
\text { experience }\end{array}\end{array}$ \\
\hline Department chair & & & $\begin{array}{l}\text { Time to complete } \\
\text { packet and } \\
\text { availability of faculty }\end{array}$ \\
\hline Full-time faculty & & & \begin{tabular}{|l} 
Communication of \\
process by Department \\
Chair-Program Director \\
-Course Coordinator
\end{tabular} \\
\hline Part-time faculty & & & $\begin{array}{l}\text { Reflection packet } \\
\text { template provided }\end{array}$ \\
\hline \multirow[t]{2}{*}{ Department staff } & & & $\begin{array}{l}\text { Difficulty level for } \\
\text { packet completion }\end{array}$ \\
\hline & & & $\begin{array}{l}\text { Training resources } \\
\text { and instructions } \\
\text { made available }\end{array}$ \\
\hline
\end{tabular}

Figure 3(c) CTQ Tree 
As a result of the baseline data collected and this being a Design for Six Sigma project, a proposed future state process map for course assessment and improvement was created by the project team identifying a closed-looped system beginning with the design or improvement of a course prior to the start of the semester and ending with the completed reflection packet being submitted to the administrative staff at the end of each semester as shown in Figure 4. By defining the process map a clear path has been presented from start to finish allowing the department to set expectations and also by including review points the ability to monitor compliance with those expectations.

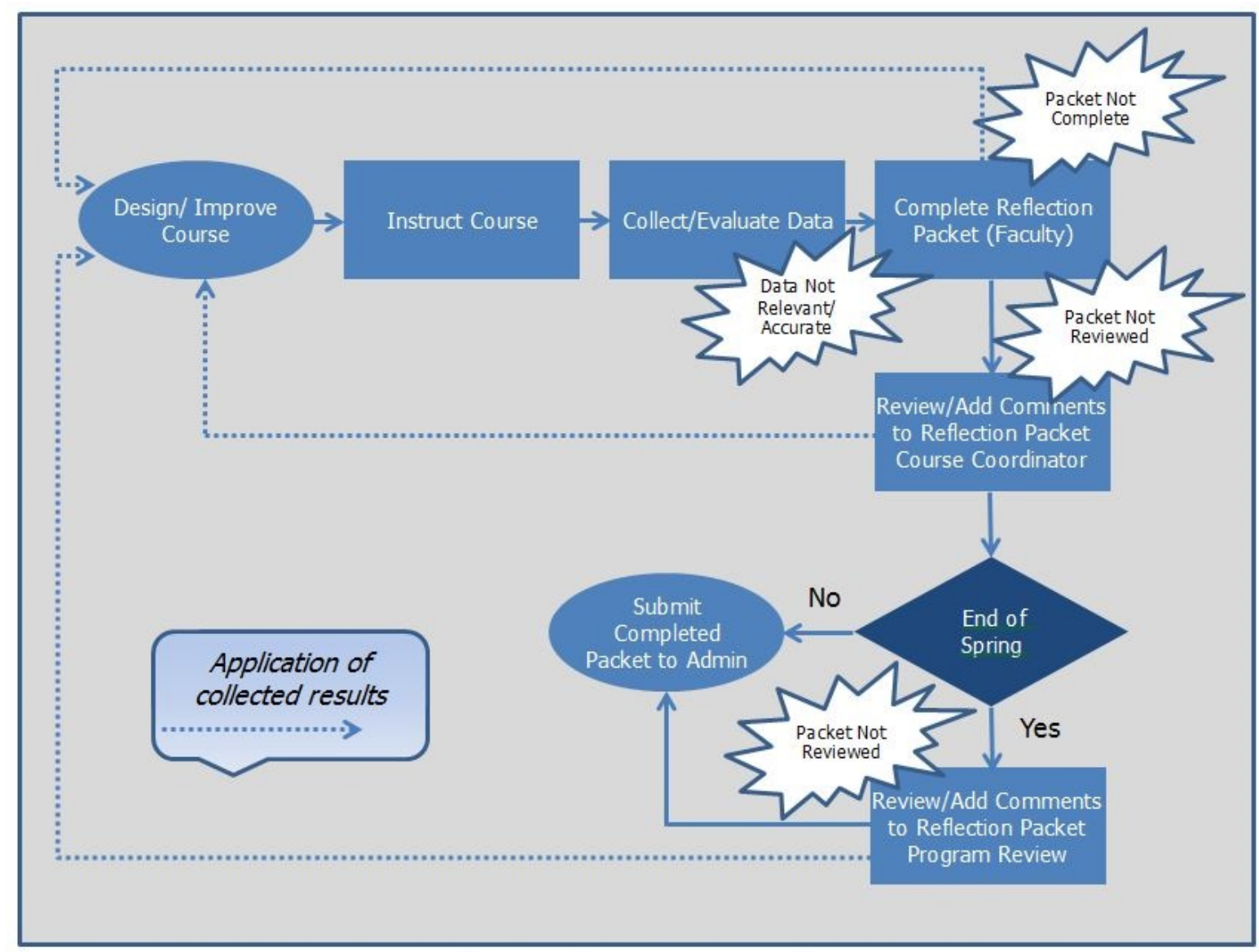

Figure 4 Proposed Future State Process Map

\section{Analyze Phase}

Once the measurement phase was completed it was time to analyze the data collected. Historical data showed that, over the last 4 semesters, $15 \%$ of faculty members completed and submitted the faculty reflection document (KPOV), a key component incorporated into the proposed faculty reflection packet. If the packet is not completed and submitted the other CTQ's cannot be evaluated. The primary operational barriers to faculty completing the reflection packet (KPOV) are the lack of communication about the process from the department chair, program directors and course coordinators (KPIV) as well as the lack of training resources and instructions made available (KPIV). Barriers were identified by indirect measurements obtained 
through surveys completed by full-time faculty members as a result of the process being new and the extensive amount of time to complete the process hasn't afforded the utilization of the process observation worksheets to provide direct measurements. The project team created a process observation worksheet to be used with the proposed process in order to assess the amount of time needed to complete each step of the process. An example of the process observation worksheet for the proposed program enrichment process is shown in Figure 5. Findings from the analyze phase revealed that $45 \%$ of full-time faculty state that there is not enough communication about the process while 55\% state that there is not a sufficient amount of training and instruction.

\begin{tabular}{|c|c|c|c|}
\hline \multicolumn{4}{|c|}{ Project Name: } \\
\hline \multicolumn{4}{|l|}{ Course Title: } \\
\hline \multicolumn{2}{|l|}{ Instructor Name: } & \multicolumn{2}{|l|}{ Term: } \\
\hline Step & Sub-process & Logged Time & Total Logged Time For Step \\
\hline \multirow{5}{*}{$\begin{array}{l}\text { New course creation } \\
\text { (if applicable) }\end{array}$} & Course site prep & & \\
\hline & Create Syllabus & & \\
\hline & $\begin{array}{l}\text { Define ABET outcomes/ } \\
\text { PULs/Course Assessment }\end{array}$ & & \\
\hline & Course content & & \\
\hline & Training & & \\
\hline \multirow{5}{*}{ Course Improvement } & Oncourse site prep & & \\
\hline & Amend Syllabus & & \\
\hline & $\begin{array}{l}\text { Define ABET outcomes/ } \\
\text { PULs/Course Assessment }\end{array}$ & & \\
\hline & Amend course content & & \\
\hline & Training & & \\
\hline \multicolumn{4}{|l|}{$\begin{array}{l}\text { Instruction } \\
\text { preparation }\end{array}$} \\
\hline \multirow{5}{*}{ Collect/Evaluate Data } & Student evaluations & & \\
\hline & $\begin{array}{l}\text { Student ABET outcomes } \\
\text { and PULs }\end{array}$ & & \\
\hline & $\begin{array}{l}\text { Course assessment } \\
\text { markers }\end{array}$ & & \\
\hline & Sample student work & & \\
\hline & Faculty reflection & & \\
\hline $\begin{array}{l}\text { Complete Reflection } \\
\text { Packet }\end{array}$ & & & \\
\hline
\end{tabular}

Figure 5 Observation Worksheet

\section{Design Phase}

Multiple solutions were generated by the project team to reduce or eliminate the impact of operational barriers. Each solution was evaluated on the basis of cost, likelihood of success, and the satisfaction of the department chair, faculty and administration. The solution matrix is shown in Figure 6. The solutions included the following suggestions:

- Include program review and comment as a step in the future state process map on an annual basis. 
- Include course coordinator review and comment as a step in the future state process map each term.

- Create a single departmental web page in Oncourse that contain links to course packets, sample completed packet and training resources as well as communication applications.

- Create a short training and question/answer session to be held annually so that it is available to new hires as well as those full and part-time faculty members that may need a refresher.

- Chair of department will include the process expectations and training as an agenda topic in the annual department kick-off meeting. The program directors will also address the topic during the part-time faculty meetings.

- Course coordinators should meet with assigned course instructors during part-time faculty meetings.

- The process expectations will become part of the new hire orientation.

- Create a single file reflection packet template including instructions.

\begin{tabular}{|c|c|c|c|c|c|c|c|c|}
\hline \multirow{3}{*}{$\begin{array}{l}\text { KPOV: Faculty } \\
\text { completed } \\
\text { reflection packet }\end{array}$} & \multicolumn{8}{|c|}{ Solution Matrix } \\
\hline & \multicolumn{8}{|c|}{ Solutions } \\
\hline & $\# 1$ & $\# 2$ & $\# 3$ & $\# 4$ & $\# 5$ & $\# 6$ & $\# 7$ & $\# 8$ \\
\hline KPIV & $\begin{array}{c}\text { oncourse } \\
\text { site }\end{array}$ & $\begin{array}{l}\text { training } \\
\& Q / A \\
\text { session }\end{array}$ & $\begin{array}{l}\text { program } \\
\text { review/ } \\
\text { comment }\end{array}$ & $\begin{array}{l}\text { coordinator } \\
\text { review/ } \\
\text { comment }\end{array}$ & $\begin{array}{c}\text { coordinator } \\
\text { meeting w/ } \\
\text { course instructor }\end{array}$ & $\begin{array}{l}\text { department kick- } \\
\text { off meeting } \\
\text { agenda }\end{array}$ & $\begin{array}{l}\text { reflection } \\
\text { packet } \\
\text { template }\end{array}$ & $\begin{array}{l}\text { new-hire } \\
\text { orientation } \\
\text { expectation }\end{array}$ \\
\hline $\begin{array}{l}\text { Communication: Department } \\
\text { Chair-Program Director-Course } \\
\text { Coordinator }\end{array}$ & 8 & 7 & 8 & 8 & 8 & 9 & 6 & N/A \\
\hline $\begin{array}{l}\text { Training Resources and } \\
\text { instructions made available }\end{array}$ & 9 & 10 & 5 & 5 & 6 & 3 & 9 & N/A \\
\hline \multicolumn{9}{|l|}{ Success Criteria } \\
\hline Likelihood of Success & 8 & 7 & 7 & 8 & 5 & 9 & 8 & N/A \\
\hline Full-time Faculty Satisfaction & 7 & 5 & 5 & 4 & 4 & 5 & 7 & N/A \\
\hline Part-time Faculty Satisfaction & 8 & 6 & 5 & 7 & 7 & 2 & 7 & N/A \\
\hline Department Chair Satisfaction & 9 & 8 & 8 & 8 & 9 & 8 & 9 & N/A \\
\hline Department Admin Satisfaction & 9 & 8 & 3 & 7 & 5 & 8 & 9 & N/A \\
\hline$\$ \$$ Cost/Revenue Impact & 2 & 4 & 2 & 5 & 3 & 1 & 5 & N/A \\
\hline Rating: High $=10$ Low $=1$ & \multirow{2}{*}{60} & \multirow{2}{*}{55} & \multirow{2}{*}{43} & \multirow{2}{*}{52} & \multirow{2}{*}{47} & \multirow{2}{*}{45} & \multirow{2}{*}{60} & \multirow{2}{*}{$\underset{* *}{\mathbf{N} / \mathbf{A}}$} \\
\hline Aggregate Score & & & & & & & & \\
\hline
\end{tabular}

Figure 6 Solution Matrix

From the solution matrix we find that \#1, the Oncourse site, and \#7, the reflection packet template rank the highest. The project team also looked at the amount of impact made in relation to the amount of effort as shown in Figure 7. The Impact/Effort matrix revealed that none of the solutions fell to the extremes, quadrant 4 being very high impact with little effort or quadrant 2 very high effort with little impact. The best solution is offered through the creation of the Oncourse site having the highest impact in relation to a lower amount of effort. The project team decided that since the project is a Design for Six Sigma, none of the solutions fell in the high effort low impact quadrant and the cost was minimal the project would utilize all of the solutions. 


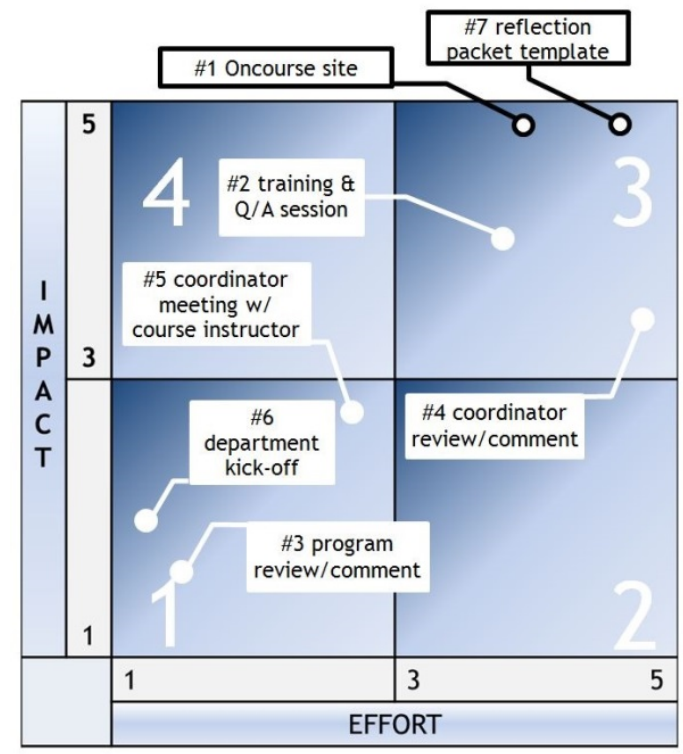

Figure 7 Impact/Effort Matrix

\section{Verify Phase - Pilot Implementation}

Pilot implementation will be conducted using a staggered implementation strategy. The project team decided to roll out the process to the program directors initially followed by revisions if necessary. Then the process would be extended to include all full-time faculty followed by full implementation, which would include part-time faculty as well, stretching implementation across 3 semesters. The pilot plan schedule is shown in Figure 8.

\begin{tabular}{|c|c|c|c|c|}
\hline & Pilot Action & $\begin{array}{l}\text { Start } \\
\text { Date }\end{array}$ & $\begin{array}{l}\text { End } \\
\text { Date }\end{array}$ & $\begin{array}{l}\text { Responsible } \\
\text { Parties }\end{array}$ \\
\hline & $\begin{array}{l}\text { Communicate pilot plan with sponsor (department chair) } \\
\text { and admin staff }\end{array}$ & $11 / 22 / 2011$ & $11 / 22 / 2011$ & VMR \\
\hline a & Prepare reflection packet rough template and format & $11 / 22 / 2011$ & $11 / 25 / 2011$ & VMR\Admin \Chair \\
\hline ם & Prepare oncourse site & $11 / 22 / 2011$ & $11 / 25 / 2011$ & VMRIAdmin \\
\hline ם & Solicit buy-in from program directors & $11 / 25 / 2011$ & $11 / 25 / 2011$ & VMR \\
\hline$\square$ & $\begin{array}{l}\text { Roll out reflection packet template to program directors } \\
\text { and admin staff (dry-run) }\end{array}$ & $11 / 25 / 2011$ & $1 / 02 / 2012$ & $\begin{array}{l}\text { VMR/Admin/Chair/ } \\
\text { Program Directors }\end{array}$ \\
\hline$\square$ & $\begin{array}{l}\text { Revise reflection packet template and oncourse site after } \\
\text { feedback is received }\end{array}$ & $1 / 02 / 2012$ & $1 / 04 / 2012$ & VMR/Admin \\
\hline ם & Create training and $\mathrm{Q} / \mathrm{A}$ session format & $1 / 02 / 2012$ & $1 / 04 / 2012$ & VMR/Admin/Chair \\
\hline Q & $\begin{array}{l}\text { Use reflection packet template to create all course specific } \\
\text { templates }\end{array}$ & $1 / 02 / 2012$ & $1 / 11 / 2012$ & Admin \\
\hline ם & Train full-time faculty members/course coordinators & $1 / 11 / 2012$ & $1 / 11 / 2012$ & VMR/Admin/Chair \\
\hline a & Roll out process to full-time faculty/course coordinators & $1 / 11 / 2012$ & $5 / 18 / 2012$ & $\begin{array}{l}\text { VMR/Admin/Chair/ } \\
\text { FT faculty/ course } \\
\text { coordinators }\end{array}$ \\
\hline ב & $\begin{array}{l}\text { Review compliance with submittal of the reflection packet } \\
\text { using data collection plan }\end{array}$ & $5 / 21 / 2012$ & $6 / 01 / 2012$ & Admin \\
\hline a & $\begin{array}{l}\text { Revise process, reflection packet, oncourse site and } \\
\text { training session from feedback }\end{array}$ & $5 / 21 / 2012$ & $6 / 01 / 2012$ & Admin \\
\hline Q & $\begin{array}{l}\text { Full scale implementation with all faculty commencing with } \\
\text { annual kick-off meeting for department, including course } \\
\text { coordinator involvement with part-time faculty meeting }\end{array}$ & $8 / 20 / 2012$ & $9 / 04 / 2012$ & Admin/Chair \\
\hline ם & Required completion of training $Q / A$ session for all faculty & $8 / 20 / 2012$ & 9/04/2012 & Chair \\
\hline & $\begin{array}{l}\text { Review compliance with submittal of reflection packet } \\
\text { using data collection plan }\end{array}$ & $1 / 07 / 2013$ & $1 / 18 / 2013$ & Admin \\
\hline
\end{tabular}

Figure 8 Pilot Plan and Schedule 
The results of the pilot plan will be reviewed and feedback from the program directors will be collected and revisions will be made where necessary. If the initial pilot is successful, the process will be fully implemented. The process includes reviews conducted by the course coordinators as well as the program to help monitor performance. The administrative staff will also be following the control plan shown in Figure 9, followed by providing compliance feedback at semester kick-off meetings.

\begin{tabular}{|c|c|c|c|c|c|c|c|}
\hline \multicolumn{7}{|c|}{ Control Plan } \\
\hline Metric & $\begin{array}{c}\text { KPOV/ } \\
\text { KPIV }\end{array}$ & Target & $\begin{array}{c}\text { Collected } \\
\text { By }\end{array}$ & Frequency & Method & Graphing & Review \\
\hline $\begin{array}{c}\text { Faculty } \\
\text { Completed } \\
\text { Reflection } \\
\text { Packet }\end{array}$ & KPOV & $90 \%$ & $\begin{array}{c}\text { Administrative } \\
\text { Staff }\end{array}$ & $\begin{array}{c}\text { end of fall } \\
\text { semester/ } \\
\text { spring } \\
\text { semester }\end{array}$ & manual & bar chart & $\begin{array}{c}\text { end of fall } \\
\text { semester/ } \\
\text { spring } \\
\text { semester }\end{array}$ \\
\hline $\begin{array}{c}\text { Faculty } \\
\text { Complied } \\
\text { with Format }\end{array}$ & KPOV & $90 \%$ & $\begin{array}{c}\text { Administrative } \\
\text { Staff }\end{array}$ & $\begin{array}{c}\text { end of fall } \\
\text { semester/ } \\
\text { spring } \\
\text { semester }\end{array}$ & manual & bar chart & $\begin{array}{c}\text { end of fall } \\
\text { semester/ } \\
\text { spring } \\
\text { semester }\end{array}$ \\
\hline $\begin{array}{c}\text { ABET } \\
\text { outcomes/ } \\
\text { PUL's } \\
\text { specified } \\
\text { were } \\
\text { collected }\end{array}$ & KPOV & $90 \%$ & $\begin{array}{c}\text { Administrative } \\
\text { Staff }\end{array}$ & $\begin{array}{c}\text { end of fall } \\
\text { semester/ } \\
\text { spring } \\
\text { semester }\end{array}$ & manual & bar chart & $\begin{array}{c}\text { end of fall } \\
\text { semester/ } \\
\text { spring } \\
\text { semester }\end{array}$ \\
\hline $\begin{array}{l}\text { Action Plan } \\
\text { Administrative staff will track KPOV's falling below target results. If a KPOV falls short of the } \\
\text { target it will be further analyzed using pre-determined stratification factors to isolate the } \\
\text { problem and take corrective measures through education, training and communication. }\end{array}$ \\
\hline
\end{tabular}

Figure 9 Control Plan

Buy-in from the program directors is vital to the diffusion of the new process and its ability to spread from full-time faculty members through to part-time faculty members on a consistent basis. The Department of Engineering Technology is also working to incorporate new software, developed by the Department of Computer Information Technology, to improve data collection. Combining efforts with other departments will also serve as a means of diffusion, taking a departmental process and using it throughout the school. Standardizing the process and the data collection will increase its sustainability by making it an inherent part of each semester's routine. The process will be truly validated through the accreditation review, while other departments are reacting to the challenge, the Department of Engineering Technology will already have its plan in place.

\section{Conclusion}

It is easy to create the appearance that a process is in place by pushing paper and crunching numbers but it is difficult to maintain momentum when the effort has no return. Now that a process has been identified, the department can monitor the collection of data and ensure that it is being submitted. Without the collection of the data there is no means for comparison. Once 
the department has established a means for comparison they can begin to evaluate the data they have collected and truly make improvements based on a systematic review rather than conjecture. This sets in motion the next project, improving the type of data being collected and ensuring that it is accurate and relevant to the task at hand. Buy-in has been an ongoing battle for the department. The idea of a champion to drive home the importance of the project is a great thought, but even good ideas will be overlooked when they are time consuming and not made to be a priority. A champion with authority or supported by someone with authority is imperative to ensure faculty compliance. This has been no easy task, pushing our planned schedule well beyond the intended time-line. May 2014 will mark the first completed cycle using the new process and the beginning of benchmarking for future comparison.

\section{Bibliography}

1. ABET. (2013). Retrieved December 28, 2013, from http://www.abet.org/DisplayTemplates/DocsHandbook.aspx?id=3143

2. Colleges USNews. (2013). Retrieved December 28, 2013, from http://colleges.usnews.rankingsandreviews.com/best-colleges/indiana-university-purdue-universityindianapolis-1813

3. Federal Student Aid. (2013). Retrieved December 28, 2013, from http://www.google.com/url?sa=t\&rct=j\&q=\&esrc=s\&source=web\&cd=1\&ved=0CDkQFjAA\&url=htt p\%3A\%2F\%2Fifap.ed.gov\%2Ffsahandbook\%2Fattachments\%2F0910FSAHbkVol2Ch1School.pdf\&e i=ZRnCUt_INYmuyQHu54HACw\&usg=AFQjCNG_lqxZvURlglb4$\underline{01 X Q 1 I \_k y d t v A \& b v m=b v .58187178, d . a W c}$

4. IUPUI Institutional Reports. (2013). Retrieved December 28, 2013, from http://reports.iupui.edu/render.aspx/INSTITUTIONAL\%20DATA/RSPINC/IUPUI

5. Indiana Commission for Higher Education. (2013). Retrieved December 28, 2013, from http://www.in.gov/che/

6. Pande, P., Neuman, R., and Cavanagh, R. (2002). The Six Sigma Way: Implementation Guide for Process Improvement Teams. New York, NY: McGraw-Hill

7. U.S. Department of Education. (2013). Retrieved December 28, 2013, from http://www2.ed.gov/admins/finaid/accred/index.html 